\title{
СОЦІАЛЬНI АСПЕКТИ
}

(C) Lysanets Yu., Bieliaieva O., Purdenko T., Ostrovska L., Morokhovets H.

UDC: $811.111^{\prime} 42$

DOI https://doi.org/10.31718/mep.2020.24.5-6.08

\section{HEDGING STRATEGIES IN THE ENGLISH ACADEMIC DISCOURSE}

\author{
Lysanets Yu., Bieliaieva O., Purdenko T., Ostrovska L., Morokhovets $H$.
}

Ukrainian Medical Stomatological Academy, Poltava, Ukraine

у статті розглянуто комунікативну стратегію ухильності (хеджингу) в англомовному академічному дискурсі. Хеджингові конструкції дозволяють автору індивідуалізувати своє судження, обмежити ступінь категоричності висловлення та уникнути абсолютного трактування. Навчання фахової англійської мови здобувачів ступеня доктора філософії та науково-педагогічних працівників - пріоритетне завдання вищої медичної освіти, у зв'язку з чим метою дослідження є вивчення і систематизація потенційних труднощів, пов'язаних із лінгвістичними конструкціями хеджування в англомовному науковому дискурсі. Доцільне використання хеджингових конструкцій розглядається авторами як важлива умова успішного спілкування, міжкультурного взаєморозуміння та міжнародного співробітництва в умовах швидкого розвитку інтеграційних процесів в Україні, що зумовлює актуальність дослідження. Проаналізовано найбільш уживані конструкції хеджування, їх значення і контекстуальну роль у фаховому мовленні. Досліджено лінгвістичні особливості маркерів хеджингу, визначено функції хеджингових конструкцій залежно від інтенції адресанта. Матеріал дослідження - зразки англомовного медичного дискурсу, отримані методом суцільної вибірки, жанри "саse report" $i$ "research article" зокрема, які містяться в електронній базі даних медичних публікацій "РubMed". Вивчення стратегій хеджування уможливлює усунення помилок й уникнення непорозумінь у медичному спілкуванні. Дослідження функціональної реалізації хеджингу на матеріалі окремих наукових жанрів англомовного медичного дискурсу конкретизує та увиразнює мовленнєву ситуацію «лікар - пацієнт», мотивує комунікативну поведінку наративних інстанцій, сприяє оптимізації міжнародної професійної комунікації. Автори вважають, що вивчення комунікативної стратегії ухильності в контексті англомовної підготовки здобувачів ступеня доктора філософії та науково-педагогічних працівників закладів вищої медичної освіти динамізує процеси науковоі співпраці, що у свою чергу сприятиме розвитку вищої медичної освіти в Україні.

Ключові слова: хеджинг, комунікативна стратегія, комунікація, академічний дискурс, адресант.

The article considers the communicative status of hedging in different genres of the English academic discourse. As a linguistic phenomenon, hedging is associated with the choice of a particular communication strategy, usually aimed at reducing the categorical nature of expressions. Hedging allows authors to limit the degree of reliability or validity of the judgment, to take off responsibility for accuracy of information in a statement, and to avoid critical interpretation. The English language training of researchers and teaching staff at medical universities has become a priority task in higher medical education. Therefore, the aim of the study was to examine and systematize the most common challenges in dealing with hedging linguistic constructions in the English academic discourse. The ability to understand and use hedging phrases correctly is an essential prerequisite of successful communication, intercultural reciprocal understanding and international cooperation in the context of rapid development of integration in Ukraine, which renders the present research relevant. The most commonly used hedging constructions, their significance and contextual role in professional communication have been analyzed. The authors have studied the linguistic features of hedging markers, and the functions of hedging constructions depending on the addresser's intentions. The material of the research is the corpus of research articles and case reports obtained by the method of continuous sampling from the electronic database of medical publications "PubMed". The analysis of hedging strategies is important to eliminate possible mistakes and avoid misunderstanding in medical communication. The study of the functional implementation of hedging on the basis of certain academic genres of the English medical discourse specifies the "doctor - patient" communicative situation, motivates the communicative behavior of narrative figures, and optimizes international professional communication. The authors believe that paying due attention to this linguistic phenomenon within the framework of the training PhDs and academic staff will promote scientific cooperation, thus contributing to the development of higher medical education in Ukraine.

Key words: hedging, communicative strategy, communication, academic discourse, addresser.

Hedging is a communicative strategy, purposefully used to weaken the illocutionary power of expression,

since without which it may sound rude, overly emotional or even aggressive [2; 4; 5]. According to G. Myers,

${ }^{*}$ To cite this English version: Lysanets Yu., Bieliaieva O., Purdenko T., Ostrovska L., Morokhovets H. Hedging strategies in the english academic discourse. // The Medical and ecological problems. - 2020. - Vol 24, № 5-6. - P. 29-31. 
"hedging is a politeness strategy when it marks a claim, or any other statement, as being provisional, pending acceptance in the literature, acceptance by the community in other words, acceptance by the readers" [7, p. 12]. As a linguistic phenomenon, hedging is associated with the choice of a particular communication strategy, usually aimed at reducing the categorical expressions. This phenomenon is also associated with such communication strategies as trying to avoid a direct expression, conceal insecurity of communicators, present information objectively, prevent possible criticism, distance oneself from misinterpretation, and limit or mitigate the truth of one's statements if communicants are not completely sure of the accuracy of the information. The material of the research is the corpus of research articles and case reports obtained by the method of continuous sampling from the electronic database of medical publications "PubMed". The study of hedging strategies is important to eliminate possible mistakes and avoid misunderstanding in medical communication. The ability to understand and use hedging phrases correctly is an essential prerequisite of successful communication, intercultural reciprocal understanding and international cooperation in the context of rapid development of integration in Ukraine, which renders the present research relevant. Quite often, the author's profound message can be concealed behind a particular choice of lexical units in a statement $[1 ; 6]$, either deliberately or unintentionally. Therefore, the authors believe that paying due attention to this linguistic phenomenon within the framework of the professional development of PhDs and academic staff will promote academic mobility, scientific cooperation and the training of foreign students to international standards, and thus contribute to the development of higher medical education in Ukraine.

The phenomenon of hedging is extremely diverse and includes many types of linguistic tools: discursive words, word-forming elements, quotation marks, whole sentences. Most often, hedging markers include: modal verbs and verbs with modal meanings (could, would, believe, guess, suppose); nouns (there is a possibility, the thing is); adverbs (quite, relatively, actually, kind of, sort of); double denial (It is not that I am not afraid); secondary sentences (You got them to do this cross-group reporting which was a good idea but the time was the problem). In linguistics, hedging strategies limit the degree of confidence in the truth of a statement and thus protect the speaker from the danger of "losing face" and experiencing communicative failure. The hedging strategy is implemented through multi-level linguistic tools. Let us consider several examples of hedging constructions, suggested by K. Hyland [3], and which are common in the English academic discourse:

- modal verbs: can, could, may, might, will, would,

- modal auxiliary verbs: seem, appear,

- epistemic verbs: assume, expect, speculate, suggest,

- adverbs, adjectives and nouns expressing probability (likely, possibly, presumably, probably, reasonable, assumption),

- approximators of quantity, frequency, time (approximately, roughly, quite, usually, generally, occasionally),

- impersonal and passive constructions.

For example, let us consider the sentence "Obesity leads to overweight babies". As we can see, this expression becomes categorical and can be interpreted as an indisputable fact. Thus, the sentence automatically be- comes controversial because it assumes that the statement is $100 \%$ true in each case, which obviously causes a number of controversies, because there will always be exceptions. Instead, the wording "Studies suggest that obesity leads to overweight babies" allows the author to distance themselves from the findings of other studies to avoid making unfounded and categorical statements.

F. Salager-Meyer [9] postulated the following categories of hedges:

1. shields: i.e. modal verbs expressing possibility, semi-auxiliaries like to appear, to seem; adverbs of probability: probably, likely, and adjectives derived from them; epistemic verbs, i.e. verbs referring to the probability of the truth of a proposition or hypothesis such as to suggest.

2. approximators: i.e. adaptors or rounders of quantity, degree, frequency and time like approximately, roughly, occasionally, quite, often etc.

3. author's personal remarks which express the author's personal doubt and direct involvement, e.g.: I believe, to our knowledge etc.

4. emotionally charged intensifiers e.g.: extremely difficult, surprisingly, unexpectedly etc.

5. compound hedges i.e. several hedges juxtaposed e.g.: it may suggest that..., it would seem likely that ...etc. [9].

Furthermore, the studies $[10 ; 11 ; 12]$ suggest another hedging taxonomy, which is also quite applicable in terms of medical academic discourse:

1. Adverbs of frequency: frequently, usually, often, occasionally, weekly, rarely...

2. Quantifiers: some, a few, a bit, a good deal, many...

3. Epistemic modality verbs: can, may, might, could, be able to, must, should, need to, to be to, will, would.

4. Epistemic lexical verbs: to seem, to appear, to believe, to assume, to suggest, to estimate, to tend, to think, to argue, to indicate, to propose, to speculate...

5. Adjectives \& adverbs: a) formal: slightly, presumably, relatively, somehow, merely, actually, partly... b) informal (diminutives): almost, (a) little, (a) few, enough, only, pretty, quite, basically, at least...

6. Nouns: assumption, claim, possibility, estimate, suggestion... that..

7. Introductory phrases: it is our view that, we feel

8. Vague references: as is known, as the reader knows...

Clusters of several types of hedging usually consist of two components (It may suggest that; It seems probable; It would indicate that), but can also be multi-component (It would seem likely that; It seems reasonable to assume that; It would seem somewhat unlikely that; It may appear somewhat speculative that).

Other examples of hedging in the analyzed discourse are: "To the best of our knowledge, this is the first case report of a multifocal (trifocal) invasive carcinoma of the breast containing osteoclast-like giant cells" [8]; "Many studies suggest that elevated triglyceride levels are associated with increased long-term risk of stroke, including transient ischemic attacks" [8]; "Food allergy is the most common cause of anaphylaxis in children and recent studies suggest increased prevalence of both food allergy and anaphylaxis" [8]; "Intelligent teenagers are more likely to drink alcohol and use cannabis than their less academically gifted peers but are less likely to smoke, new study results suggest" [8]; "As is known, 
cancer-associated fibroblasts usually facilitate tumor progression by releasing cytokines and providing a niche for cancer stem cells" [8]; "It appears that diabetes, dementia and hypoglycemia are inextricably linked in older patients with diabetes" [8]; "From this it would seem likely that chronic injuries are due to repetitive training or from minor non-contact injuries repeated intermittently" [8]; "It may suggest that treatment discontinuation could be considered for one in three long-term users." [8]; "Age, type of stimulus, comorbidities, and study design but not necessarily gender appear to influence the reported prevalence of cold stimulus headache" [8]; "Collectives in organizations appear less morally motivated than individuals" [8]; "Nonetheless, it would seem likely that chronic treatment with an SRI in adults might result in neuroplastic changes in the serotonin system" [8]. Hence, hedging allows us to limit the degree of reliability or validity of the judgment, to take off responsibility for accuracy of information in a statement, to avoid critical interpretation.

Thus, the functioning of non-categorical utterances in the English academic communication is determined by the norms of academic style, ethnocultural factor and pragmatics of the speech act. The ability to correctly apply and interpret hedging is one of the main communicative competencies required to master a foreign language at a high level. In our opinion, further study of hedging in academic discourse is a promising area, which is important for successful intercultural communication and the development of translation theory. In particular, it is necessary to focus on the frequency of specific lexical units of hedging within the analyzed corpus of publications.

\section{References}

1. Berezhans'ka Yu. V. Lingvostilistichni osoblivosti persuazivnogo medichnogo diskursu, prisvyachenogo problemi evtanaziï. Naukovi za-piski Nazional'nogo universitetu "Ostroz'ka akademiya". Seriya Filologichna : zbirnik naukovich praz'. Ostrog : Vidavniztvo
Nazional'nogo universitetu "Ostroz'ka akademiya", 2014; 44: $39-41$

2. Crompton P. Hedging in Academic Writing: Some Theoretical Problems. English For Specific Purposes. 1997; 16(4): 271-287.

3. Hyland K. Hedging in Academic Writing and EAP. English for Specific Purposes. 1994; 3: 239-256.

4. Lewin B. A. Hedging: an Exploratory Study of Authors' and Readers' Identification of 'Toning Down' in Scientific Texts. Journal of English for Academic Purposes. 2005; 4:163178.

5. Leyla S. Atai M. A Cross-Cultural Study of Hedging Devices in Discussion Section of Applied Linguistics Research Articles.Teaching English language and literature society of Iran. 2008;7:1-22.

6. Lysanets Yu., Morokhovets H., Bieliaieva O. Stylistic Features of Case Reports as a Genre of Medical Discourse Journal of Medical Case Reports. 2017; 11: 83. - Access mode

https://imedicalcasereports.biomedcentral.com/articles/10. 1186/s13256-017-1247-x

7. Myers G. The Pragmatics of Politeness in Scientific Articles. Applied Linguistics.1989;10: 1-35.

8. PubMed [Electronic resource]. - Access mode: // https://pubmed.ncbi.nlm.nih.gov/

9. Salager-Meyer F. Hedges and Textual Communicative Function in Medical English Written Discourse. ESP Journal.1994;13(2):149-169.

10. Uysal H.A. Cross-Cultural Study of Indirectness and Hedging in the Conference Proposals of English NS and NNS Scholars. Occupying Niches: Interculturality, CrossCulturality and Acculturality in Academic Research [Eds. A. Lyda, \& Warchal, K.]. 2014:179-195.

11. Varttala, T. Remarks on the Communicative Functions of Hedging in Popular Scientific and Specialist Research Articles on Medicine. English for Specific Purposes.1999; 2: 177-200

12. Yagıza O., Demirb C. Hedging Strategies in Academic Discourse: A Comparative Analysis of Turkish Writers and Native Writers of English. Procedia: Social and Behavioral Sciences.2014;158 (19): 260-268.

Матеріал надійшов до редакції 04.10.2020 